\title{
Biofilm forming antimicrobial-multiresistant Staphylococcus aureus
}

\author{
Multirresistência antimicrobiana de Staphylococcus \\ aureus formadores de biofilme
}

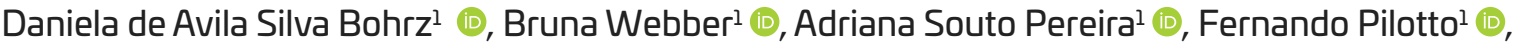 \\ Luciana Ruschel dos Santos² (1), Laura Beatriz Rodrigues²* (])
}

\begin{abstract}
Staphylococcus aureus is one of the main agents isolated from bovine mastitis cases, characterized by lower cure rates compared to other pathogens causing this disease. This phenomenon is mainly explained by the multiresistance acquisition to antimicrobials and the ability of $S$. aureus to form biofilms on biotic and abiotic surfaces. In this work 15 samples of $S$. aureus isolated from the automated milking facility were analyzed regarding the resistance profile to antimicrobials, virulence factors (capsule production, hemolysin, and protease) and adhesion capacity under different temperatures $\left(42 \pm 1^{\circ} \mathrm{C}, 36 \pm 1^{\circ} \mathrm{C}, 25 \pm 1^{\circ} \mathrm{C}, 9 \pm 1^{\circ} \mathrm{C}\right.$, and $\left.3 \pm 1^{\circ} \mathrm{C}\right)$. All isolates showed methicillin-resistant (MRSA) characteristics and multidrug resistance profile to the antimicrobials tested (penicillin $\mathrm{G}$, chloramphenicol, oxacillin, cephalexin, tetracycline, amoxicillin + clavulanic acid, sulfa + trimetropim, gentamicin, doxycycline, ceftiofur, neomycin, and vancomycin) with an IRMA index between 0.5 and 1.0. Five isolates were resistant to vancomycin (VRSA), two were resistant to all active principles, and the others to at least six of these drugs. Adhesion capacity and biofilm formation were found in 3 of the 5 evaluated temperatures, including the cooling conditions. Regarding the virulence factors, $86.7 \%$ of the isolates formed capsules, $60 \%$ revealed the presence of protease, $26.7 \%$ expressed the $\alpha$-hemolysin factor, and $13.3 \%$ of them presented $\beta$-hemolysin. The fact that all isolates presented MRSA characteristics represents a potential risk to those exposed to this agent, and the formation of biofilm in liners even after the use of detergents and sanitization highlights the urgency of searching for alternatives for dispersion of the biofilm by $S$. aureus in the automated milking facility.
\end{abstract}

KEYWORDS: mastitis, virulence factors, adhesion on surfaces.

RESUMO: O Staphylococcus aureus é um dos principais agentes isolados de casos de mastite bovina, caracterizado por menores taxas de cura em comparação com outros patógenos desta enfermidade. Esse fenômeno é explicado principalmente pela aquisição de resistência à antimicrobianos e a capacidade do $S$. aureus formar biofilmes em superficies bióticas e abióticas. Neste trabalho foram utilizadas 15 amostras de $S$. aureus isolados de ordenhadeira, analisados quanto ao perfil de resistência à antimicrobianos, fatores de virulência (produção de cápsula, hemolisina e protease) e capacidade de adesáo sob diferentes temperaturas $\left(42 \pm 1^{\circ} \mathrm{C}, 36 \pm 1^{\circ} \mathrm{C}, 25 \pm 1^{\circ} \mathrm{C}, 9 \pm 1^{\circ} \mathrm{C}\right.$ e $\left.3 \pm 1^{\circ} \mathrm{C}\right)$. Todos os isolados apresentaram perfil de multirresistência aos antimicrobianos testados (penicilina G, cloranfenicol, oxacilina, cefalexina, tetraciclina, amoxicilina + ácido clavulônico, sulfa + trimetropim, gentamicina, doxiciclina, ceftiofur, neomicina e vancomicina) com índice IRMA entre 0,5 a 1,0. Duas cepas foram resistentes a todos os princípios ativos e as demais a pelo menos seis destes fármacos. Os isolados avaliados apresentaram característica de meticilina-resistentes (MRSA) e destes, 33,34\% (5/15) foram resistentes à vancomicina (VRSA). Houve capacidade de adesão e formação de biofilmes em 3 das 5 temperaturas avaliadas, incluindo as temperaturas de refrigeração. Em relação aos fatores de virulência, $86,7 \%$ dos isolados formaram cápsula, $60 \%$ presença de protease, $26,7 \%$ expressaram o fator $\alpha$-hemolisina e $13,3 \% \beta$-hemolisina. O fato de todos isolados apresentarem característica MRSA representa um risco potencial aos expostos a esse agente. Já a formação de biofilmes em teteiras, mesmo após detergência e sanitização, destacam a urgência de alternativas de dispersão de biofilmes no ambiente de ordenha.

PALAVRAS-CHAVE: mastite, fatores de virulência, adesão nas superfícies. 


\section{INTRODUCTION}

Bovine mastitis is an inflammation of the mammary glands that negatively affects the dairy industry, with strong negative consequences for animal welfare, food safety, and productivity, leading to economic losses due to reduced milk production and increased costs of clinical treatment (SCHUKKEN et al., 2011; HEIKKILÄ et al., 2018). Staphylococcus aureus is one of the main agents causing subclinical and clinical mastitis in dairy cattle (RALL et al., 2014; BONSAGLIA et al., 2018). However, unlike clinical mastitis, subclinical mastitis shows few visible symptoms in infected cows (VIGUIER et al., 2009; LE MARÉCHAL et al., 2011), and this failure to detect this disease rapidly leads to a high prevalence of $S$. aureus infections in dairy farms (GRUET et al., 2001).

Several characteristics contribute to the pathogenesis and spread of $S$. aureus, including virulence factors, host, and environment (ACOSTA et al., 2018). Its ability to adhere and form biofilms on biotic and abiotic surfaces significantly increases the persistence of this pathogen in equipment and facilities, providing a physiological advantage as an etiological agent of diseases caused by food consumption, especially through the consumption of milk and its derivatives (MERGHNI et al., 2015; WANG et al., 2018; REN et al., 2020)

The formation of biofilms contributes to the resistance to antimicrobials (MELCHIOR et al., 2006; RAZA et al., 2013). Moreover, the excessive use of antimicrobials has been shown to favor the emergence and selection of resistant bacteria, altering the structure of bacterial communities and inducing a rapid evolution, with unpredictable consequences for human and animal health (VAZ-MOREIRA; NUNES;
MANAIA, 2014). Thus, the prevention and control of staphylococcal mastitis are vital for the entire milk production chain, since this disease requires an increased use of antimicrobials in dairy herds (STEVENS et al., 2018).

In this context, 15 samples of $S$. aureus isolated from the automated milking environment were analyzed regarding the antimicrobial resistance profile, virulence factors, and adhesion ability under different temperatures.

\section{MATERIALS AND METHODS}

Microbiological tests were performed at the Laboratory of Bacteriology and Veterinary Mycology of the Veterinary Hospital of the Faculdade de Agronomia e Medicina Veterinária, Universidade de Passo Fundo (FAMV/UPF)

We analyzed 15 samples of $S$. aureus isolated from different points of the automated milking facility on a dairy farm in northern Rio Grande do Sul state, Brazil. The sample identification and the site of isolation are described in Table 1.

For isolating $S$. aureus, $25 \mathrm{~mL}$ of the samples were homogenized in $225 \mathrm{~mL}$ of Buffered Peptone Water (BPW, Laborclin ${ }^{\circledR} 1$ ) and, after a series of decimal dilutions, a $0.1 \mathrm{~mL}$ aliquot of each sample was seeded on plates containing Agar Baird-Parker (ABP, Laborclin ${ }^{\circledR} 1$ ), which were incubated at $36 \pm 1^{\circ} \mathrm{C}$ for 48 h (EVANCHO et al., 2001). S. aureus compatible colonies were submitted to Gram staining and biochemical catalase, coagulase, DNAse, and Voges-Proskauer testing. The results were expressed as $\log 10$ UFC. $\mathrm{cm}^{2}$.

In order to evaluate sensitivity to antimicrobials by discdiffusion, pure colonies of $\mathrm{S}$. aureus were incubated in Brain Heart Infusion broth (BHI, HiMedia ${ }^{\circledR} 3$ ) at $36 \pm 1^{\circ} \mathrm{C}$ for 16

Table 1. Identification of samples of $S$. aureus isolated from different points of the milking facility.

\begin{tabular}{c|c|c|c} 
Sample & Bacteria species & Points at the milking facility & Place of collection \\
ST1 & S. aureus & Liners with milk residues & Rio Grande do Sul \\
\hline ST2 & S. aureus & Water from the $1^{\text {st }}$ rinse of the CIP process & Rio Grande do Sul \\
\hline ST3 & S. aureus & Milk from the cluster & Rio Grande do Sul \\
\hline ST4 & S. aureus & Liners after detergency & Rio Grande do Sul \\
\hline ST5 & S. aureus & Liners after sanitizing and detergency & Rio Grande do Sul \\
\hline ST6 & S. aureus & CIP water after sanitizing and detergency & Rio Grande do Sul \\
\hline ST7 & S. aureus & Liners after sanitizing & Rio Grande do Sul \\
\hline ST8 & S. aureus & Rinse water from CIP piping, after sanitizing & Rio Grande do Sul \\
\hline ST9 & S. aureus & Liners with milk residues & Rio Grande do Sul \\
\hline ST10 & S. aureus & Water from the $1^{\text {st } \text { rinse of the CIP process }}$ & Rio Grande do Sul \\
\hline ST11 & S. aureus & Milk from the milking cluster & Rio Grande do Sul \\
\hline ST12 & S. aureus & Tank with residues after removing milk from the cluster & Rio Grande do Sul \\
\hline ST13 & S. aureus & Tank after detergency & Rio Grande do Sul \\
\hline ST14 & S. aureus & Liners after detergency & Rio Grande do Sul \\
\hline ST15 & S. aureus & CIP water after detergency & Rio Grande do Sul \\
\hline
\end{tabular}

CIP: Clean-in-Place. Internal cleaning process of a part or equipment without relocation or disassembly, automatically recirculating the detergent and rinsing solutions. 
to $18 \mathrm{~h}$ and a suspension equivalent to MacFarland8 scale obtained by dilution was used for inoculation of test bacteria in Agar Mueller-Hinton ( $\left.\mathrm{MH}, \mathrm{Oxoid}^{\circledR} 2\right)$. After seeding the plate, a commercial paper disc (Laborclin $\left.{ }^{\circledR} 1\right)$ containing the defined concentration of the antimicrobial being evaluated was applied on the agar. The disc-diffusion test was performed according to the recommendations of CLSI (CLSI, 2019) and BrCAST (BRCAST, 2017) against the following active principles: Cephalexin (CFE) $30 \mu \mathrm{g}$, Gentamicin (GEN) $10 \mu \mathrm{g}$, Tetracycline (TET) $30 \mu \mathrm{g}$, Oxacillin (OXA) $1 \mu \mathrm{g}$, Neomycin (NEO) $30 \mu \mathrm{g}$, Sulfa + Trimetropim (SUT) $25 \mu \mathrm{g}$, Penicillin G (PEN) $10 \mathrm{U}$, Amoxicillin + Clavulonic Acid (AMC) 30 $\mu \mathrm{g}$, Vancomycin (VAN) $30 \mu \mathrm{g}$, Chloramphenicol (CLO) 30 $\mu \mathrm{g}$, Doxycycline (DOX) $30 \mu \mathrm{g}$ and Ceftiofur (CTF) $30 \mu \mathrm{g}$.

After incubation at $36 \pm 1^{\circ} \mathrm{C}$ for $24 \mathrm{~h}$ the inhibition halos were read and interpreted according to a specific table. We used the criterion for multi-drug resistance of the National Antimicrobial Resistance Monitoring System (NARMS, 2012) which cites multi-drug resistance as a resistance to three or more classes of antimicrobials and also by specific phenotypes.

The data obtained by disc-diffusion were submitted to Analysis of Variance (ANOVA), and the means of halos were compared by the Tukey test, both at $5 \%$ significance. The multiple antimicrobial resistance index (IRMA) for each sample was calculated according to KRUMPERMAN (1983), through the ratio between the number of resistant antibiotics and the total number of antibiotics tested.

The ability of $S$. aureus to produce capsules as a presumptive test for biofilm formation was determined by the Congo Red Agar (CRA, Difco ${ }^{\mathrm{TM} 4}$ ) plate culture described by FREEMAN; FALKINER; KEANE (1989). CRA ${ }^{4}$ was prepared from 37g.L-1 Brain Heart Infusion broth (BHI, HiMedia $^{\circ 3}$ ), 50 g.L-1 sucrose (Difco ${ }^{\text {TM4 }}$ ), 15 g.L-1 Base Agar (DifcoTM4) and 0.8 g.L-1 Congo Red Dye (Difco $\left.{ }^{\mathrm{TM} 4}\right)$. S. aureus colonies obtained overnight in Soya Triptone Broth $\left(\mathrm{TSB}, \mathrm{Merck}^{5}\right.$ ) were inoculated in $\mathrm{CRA}^{4}$ and incubated at $36^{\circ} \pm 1^{\circ} \mathrm{C}$ for $24 \mathrm{~h}$. Samples considered to be capsule-producing showed black coloring and those regarded as not producing present a red color.

Hemolysin production was evaluated according to the methodology described by DIAS et al. (1994). After $24 \mathrm{~h}$ of incubation in Agar Triptone Soy (TSA, Difco ${ }^{\mathrm{TM} 4}$ ) bacterial cultures were inoculated in Blood Agar plates (TSA with 5\% sheep blood, Laborclin $\left.{ }^{\circ}\right)$ and incubated at $36^{\circ} \pm 1^{\circ} \mathrm{C}$ for $48 \mathrm{~h}$. The presence of circular zones of total $(\beta)$ or partial $(\alpha)$ hemolysis around the colonies indicated positive results for the test.

Protease production was determined in Agar Milk (Milk HiVeg ${ }^{\mathrm{TM}}$ Agar, HiMedia ${ }^{\circ}$ ) according to BUDI et al. (2001). After incubating the bacterial cultures in TSB 5 broth at $36^{\circ} \pm 1^{\circ} \mathrm{C}$ for $24 \mathrm{~h}$, the colonies were inoculated into Agar Milk ${ }^{3}$ plates and incubated at $36^{\circ} \pm 1^{\circ} \mathrm{C}$ for $48 \mathrm{~h}$. The presence of degradation, visualized as a clear halo around the colonies, indicated positive results for the assay.
The ability to adhere under different temperatures and the detection of biofilm formation on polystyrene surface was performed by the microplate (MP) method described by RODRIGUES et al. (2010). The strains were incubated on $\mathrm{TSA}^{4}$ agar with $4 \%$ glucose at $36 \pm 1^{\circ} \mathrm{C}$ for $24 \mathrm{~h}$. Then, they were grown in $3 \mathrm{~mL}$ of TSB ${ }^{5}$ broth with $4 \%$ glucose and incubated at $36^{\circ} \pm 1^{\circ} \mathrm{C}$ for $24 \mathrm{~h}$. Each sample was then diluted in 1 $\mathrm{mL}$ of TSB ${ }^{5}$ broth with $4 \%$ glucose to the score of MacFarland scale ${ }^{8}$. Each sample was inoculated $200 \mu \mathrm{L}$ of bacterial suspension in three separate wells into 96-well flat-bottomed polystyrene plate, with each plate incubated at $42 \pm 1^{\circ} \mathrm{C}, 36 \pm 1^{\circ} \mathrm{C}$, $25 \pm 1^{\circ} \mathrm{C}, 9 \pm 1^{\circ} \mathrm{C}$, and $3 \pm 1^{\circ} \mathrm{C}$ for $24 \mathrm{~h}$. As a negative control, non-inoculated $\mathrm{TSB}^{5}$ broth was used, also in triplicate.

After the period, the bacterial suspension of each well was aspirated and washed three times with $250 \mu \mathrm{L}$ sterile $0.9 \%$ sodium chloride solution. After that, the bacterial cells were fixed with $200 \mu \mathrm{L}$ of methanol p. a. for 15 min with subsequent removal. The plates were dried at room temperature and stained with $200 \mu \mathrm{L}$ of Hucker's $2 \%$ violet crystal solution for $5 \mathrm{~min}$, then washed and dried again at room temperature. The procedures were performed in duplicate and each sample yielded 6 replicates for reading, at each evaluated temperature.

The absorbance reading was performed in a ELISA reader at $550 \mathrm{~nm}$. The absorbance value of each sample (DOa) was obtained from the arithmetic mean of the values of the 6 wells and compared with the absorbance mean of the noninoculated $\mathrm{TSB}^{5}(\mathrm{DO})$. To determine the degree of adhesion the following classification was used: non-adherent: $\mathrm{DOa} \leq$ DO; low adhesion: $\mathrm{DO}<\mathrm{DOa} \leq 2 . \mathrm{DO}$; moderately adherent: $2 . \mathrm{DO}<\mathrm{DOa} \leq 4 . \mathrm{DO}$; strongly adherent: $4 . \mathrm{DO}<\mathrm{DOa}$

\section{RESULTS AND DISCUSSION}

In the disc-diffusion antimicrobial sensitivity test, all analyzed S. aureus isolates showed a pattern of multidrug resistance to antimicrobials tested with Multiple Antimicrobial Resistance (MAR) Index $\geq 0.5$, being resistant to three or more classes of antimicrobials (Table 2).

According to KRUMPERMAN (1983), MAR Antimicrobial Resistance indices $\geq 0.2$ reveal the phenomenon of multidrug resistance (MDR), indicating a risk to public health since it impairs the disease treatment. The results found in this study were superior than those reported by DA COSTA et al. (2013), in which the MAR index for $S$. aureus varied from 0 to 0.26 . However, the author pointed out that $18.15 \%$ of the samples presented MAR index $\geq 0.2$, characterizing multiresistance. MDR bacteria develop resistance in response to the antibiotics used and the same strains can colonize animals and humans, being easily disseminated among bacterial species or phylogenetically related clones (MANYI-LOH, CHRISTY et al., 2018).

Since 2013, the use of antibiotics as an additive has been suspended by the European Community based on the precautionary principle (HUYGHEBAERT; DUCATELLE; VAN 
IMMERSEEL, 2011). To meet international requirements, Brazil has gradually established, through various legal regulations, a stricter use of antibiotics and other performanceenhancing additives. Thus, the following drugs were banned: avoparcin in 1998; antimony compounds in 2002; chloramphenicol and nitrofurans (including veterinary clinical use) in 2003; olaquindox in 2004; carbadox in 2005; amphenicols, tetracyclines, beta-lactams (benzylpenicillin and cephalosporins), quinolones and sulfonamides in 2009; spiramycin and erythromycin in 2012; and colistin in 2016 (RABELLO et al., 2020). Recently, tylosin, lincomycin, and tiamulin additives were banned in Brazil, although virginiamycin and bacitracin are still allowed (BRAZIL, 2020).

All the strains analyzed for antimicrobial susceptibility showed characteristics of methicillin-resistant strains (MRSA), being $100 \%$ resistant to penicillin G; $93.34 \%$ to oxacillin (MRSA) and the association amoxicillin + clavulanic acid; and $33.34 \%$ of these also showed resistance to vancomycin (VRSA).

The recent debate on the high resistance of $S$. aureus MRSA strains, particularly in human medicine, has increased concern about the use of antimicrobials in dairy cow therapy. Even with methicillin out of production, due to the use of more stable penicillin such as oxacillin, the term MRSA is still used for penicillin-resistant $S$. aureus. Penicillin-stable penicillin (PSSP), of which methicillin is a prototype, are semi-synthetic drugs developed to treat infections caused by $S$. aureus, a beta-lactamase producer (BASSETTI et al., 2019). S. aureus MRSA strains are resistant to all beta-lactam agents except new fifth-generation cephalosporins, and are often MDRs, which can result in higher costs, prolonged treatment times, and higher rates of hospitalization and comorbidities (KHAN
\& KHAN, 2015). The fact that all the isolates in this study exhibited MRSA characteristics in the milking environment represents a potential risk to workers, veterinarians, and animals exposed to this agent (MENEGOTTO \& PICOLI, 2007).

Although glycopeptides are not commonly used in the treatment of bovine mastitis, isolates have been evaluated for vancomycin susceptibility due to their importance in the treatment of human infections, reported to be the most effective antibiotic for gram-positive bacteria, including MRSA strains (LUNDSTROM \& SOBEL, 2000). However, increased use of vancomycin led to the emergence of vancomycin-resistant S. aureus (HIRAMATSU et al., 1997). This fact corroborates the findings of this study, in which an emerging $33.34 \%$ resistance to vancomycin was identified. These isolates also formed biofilms, with $S$. aureus being an effective antagonist to vancomycin, erfloxacin, and teicoplanin; acting as a barrier to these compounds or even interfering in their action on cell membrane (SOULI \& GIAMARELLOU, 1998).

RESENDE et al. (2012) found that ciprofloxacin showed a $100 \%$ action on milk isolates from cows with mastitis, followed by gentamicin $(95.45 \%)$, sulfazotrim $(86.36 \%)$, and chloramphenicol (86.36\%). The highest resistance rates were verified for cefepime (95.45\%) and penicillin G (81.82\%). These results differ from those found in our study, in which the highest resistance rates were found for chloramphenicol (100\%), sulfa+trimetropim (93.33\%), and gentamicin (80\%).

Clindamycin, gentamicin, and ciprofloxacin are commonly used in the treatment of bovine mastitis in Brazil, and it is suggested that these drugs are responsible for triggering a selective pressure on dairy farms. In fact, $80 \%$ of the isolates in this study showed resistance to gentamicin. In addition, all

Table 2. Antimicrobial resistance profile e Multiple Antimicrobial Resistance (MAR) Index of 15 isolates of S. aureus.

\begin{tabular}{c|c|c|c} 
Sample & Antimicrobial resistance pattern & $\begin{array}{c}\text { Antimicrobial } \\
\text { resistance profile }\end{array}$ & 1 \\
IRMA
\end{tabular}


isolates from dairy farms in the Northeast of Brazil, reported in the work of SILVEIRA-FILHO et al. (2014), were resistant to gentamicin and bacitracin, which denotes the high rate of $S$. aureus resistant to gentamicin on dairy farms in different regions of Brazil. FREITAS et al. (2018), when identifying $S$. aureus in dairy properties of Rio Grande do Sul, found that $96.7 \%$ of the isolates were resistant to tetracycline, gentamicin (86.7\%), and neomycin (96.7\%).

Ceftiofur, a third generation cephalosporin, and the only one approved for farm animals (SATO et al., 2014), was the drug with the lowest resistance (33.34\%) in this study. This group of antimicrobials prevents the synthesis of the cell wall, responsible for the functions of protection, support, and maintenance of the bacterial morphology (AULETTA et al., 2016).

For PÉREZ-RODRÍGUEZ \& MERCANOGLUTABAN (2019) the excessive and indiscriminate use of antimicrobials for therapy and prophylaxis of bacterial infections in production animals are promoting the development of multi-resistant pathogens to commonly used drugs. Microbial resistance is the ability inherited from microorganisms to multiply in the presence of antibiotics, regardless of the duration of treatment (LEVIN-REISMAN et al., 2019).

All $S$. aureus isolates formed biofilms at different temperatures and degrees of adherence. Only one sample (ST13) did not form biofilms at $3^{\circ} \mathrm{C}$. Regarding virulence factors, $86.7 \%$ of the strains formed capsules, $60 \%$ showed the presence of protease, $26.7 \%$ expressed the factor $\alpha$-hemolysin and $13.3 \%$ $\beta$-hemolysin (Table 3).

It is important to highlight the detection of biofilm formation at $3^{\circ} \mathrm{C}$, since this temperature is considered safe for the transport and conservation of milk on the farm. According to IN 77 (BRAZIL, 2018), in the case of a direct expansion refrigeration tank, the temperature for milk storage must be equal to or below $4^{\circ} \mathrm{C}$, for a maximum time of 3 hours, regardless of its capacity, with the performance and efficiency characteristics according to specific technical regulations. The temperature of cooled raw milk in transport and reception should not exceed $7^{\circ} \mathrm{C}$, exceptionally allowing its reception at up to $9^{\circ} \mathrm{C}$.

Of the 15 isolates, $40 \%$ were classified as strongly adherent, i.e., strongly biofilm forming. GUIMARÁES et al. (2012), when studying the production of biofilm by Staphylococcus, obtained different results from those observed in our study, because 13/30 (43.3\%) of the strains analyzed did not form biofilms and only 8/30 (26.7\%) were strongly biofilm formers.

OLIVEIRA et al. (2006), working with mastitis isolates, found $18.7 \%$ of the $S$. aureus strains producing biofilms, while NOEL et al. (2016), who studied a biofilm formation in Staphylococcus spp. also from bovine mastitis, but in the Rio de Janeiro state, detected biofilms in $74.4 \%$ of the isolates. STEPANOVIC et al. (2000) emphasized that the plate adherence test is one of the most used methods to quantify biofilms produced by Staphylococcus spp.

An important characteristic of $S$. aureus is its ability to form biofilms on biological and inert surfaces. In relation to mastitis, the adhesions of $S$. aureus to the epithelium of the mammary gland are considered the first critical point in the pathogeny of this disease, because the biofilm helps in the adherence and colonization of microorganisms in the epithelium of the mammary gland (MELO et al., 2012). Thus, in many clinical cases, the immune response of the host to

Table 3. Biofilm formation and virulence factors of 15 isolates of $S$. aureus.

\begin{tabular}{|c|c|c|c|c|c|c|c|c|}
\hline \multirow{2}{*}{ Sample } & \multicolumn{5}{|c|}{ Adhesion at 550nm } & \multicolumn{3}{|c|}{ Virulence factors } \\
\hline & $3^{\circ} \mathrm{C}$ & $9^{\circ} \mathrm{C}$ & $25^{\circ} \mathrm{C}$ & $36^{\circ} \mathrm{C}$ & $42^{\circ} \mathrm{C}$ & Capsule & Protease & Hemolysin \\
\hline ST 1 & WEAK & WEAK & MODERATE & WEAK & MODERATE & + & + & - \\
\hline ST2 & MODERATE & WEAK & MODERATE & STRONG & STRONG & + & + & $+\beta$ \\
\hline ST3 & WEAK & MODERATE & MODERATE & STRONG & STRONG & + & - & $+\alpha$ \\
\hline ST4 & WEAK & WEAK & MODERATE & WEAK & WEAK & + & + & - \\
\hline ST5 & WEAK & STRONG & WEAK & STRONG & STRONG & + & + & $+\beta$ \\
\hline ST6 & WEAK & WEAK & WEAK & STRONG & STRONG & + & - & $+\alpha$ \\
\hline ST7 & WEAK & MODERATE & MODERATE & STRONG & STRONG & + & + & - \\
\hline ST8 & WEAK & WEAK & STRONG & STRONG & STRONG & + & - & $+\alpha$ \\
\hline ST9 & WEAK & WEAK & MODERATE & WEAK & MODERATE & + & + & - \\
\hline ST 10 & WEAK & WEAK & WEAK & STRONG & STRONG & + & - & $+\alpha$ \\
\hline ST 11 & WEAK & WEAK & WEAK & MODERATE & MODERATE & + & + & - \\
\hline ST 12 & WEAK & WEAK & WEAK & MODERATE & MODERATE & + & + & - \\
\hline ST 13 & - & WEAK & MODERATE & MODERATE & STRONG & - & - & - \\
\hline ST 14 & MODERATE & MODERATE & STRONG & STRONG & STRONG & - & - & - \\
\hline ST 15 & WEAK & WEAK & MODERATE & MODERATE & MODERATE & + & + & - \\
\hline
\end{tabular}


persistent infections is ineffective and may result in chronic conditions (ARCHER et al., 2011).

Although the effect of surface roughness on biofilm formation is contradictory in the literature (MARCHAND et al., 2012), the results of biofilm on liners with milk residues from milking and on clean liners, even after detergency and sanitization, highlight the urgency of alternative measures for biofilm dispersion. LATORRE et al. (2010) observed biofilms on liners, mainly associated with scratches on their surface, using scanning electron microscopy.

Regarding virulence factors, $S$. aureus is able to develop several mechanisms to escape from immune responses. To resist phagocytic depuration, this pathogen expresses a polysaccharide capsule, which effectively masks the bacterial surface and the proteins associated with the surface, the opsonins, resulting in a higher virulence and tissue invasion ability from a peripheral focus, prolonging the persistence of the pathogen in the bloodstream of the host (O'RIORDAN \& LEE, 2004). In addition, the enhancement of $S$. aureus pathogenesis is determined by the secretion of proteases that cleave specific components of the host immune system or disturb the integrity of the extracellular matrix and intercellular connections, compromising the stability of host tissues and contributing to the spread of infection (KOZIEL \& POTEMPA, 2013).

$S$. aureus is one of the most common human and animal pathogens. Some staphylococcal species produce hemolysins that differ according to the lytic action on erythrocytes. Bovine strains produce mainly beta-hemolysin, while human isolates have the ability to produce alpha-hemolysin (ECONOMOU \& GOUSIA, 2015). Beta- and alpha-type strains are also important in the pathogenesis of intramammary infections in dairy cattle due to the induction of proinflammatory changes in the cells, inactivating the immune system by their direct cytotoxic effect and by degrading tissues (ZSCHOCK et al., 2005). MARQUES et al. (2013) found only 13.2\% (33/250) hemolytic Staphylococcus spp. Of these, $48.5 \%$ (16/33) presented total hemolysis, 36.4\% (12/33) partial hemolysis, and 15.1\% (5/33) partial hemolysis. CHIH-WEI; YIU-KAY; YU-TSUENG (2011) defines the production of hemolysins as decisive for the pathogenicity of microorganisms, since by degrading tissues, they allow the invasion and dissemination pf the pathogen, besides escaping the immune response of the host.
Alpha hemolysin is considered by some authors as one of the main pathogenicity factors of this bacterium due to its hemolytic, dermonecrotic, and neurotoxic effects (DINGES; ORWIN; SCHLIEVERT, 2000). LARSEN; AARESTRUP; JENSEN (2002) suggested that strains of Staphylococcus spp. producing partial hemolysis are more virulent to cattle than non-hemolytic strains. Partial hemolysis in Staphylococcus spp. is represented by beta-hemolysin, which is toxic to several cell types and relevant in cases of mastitis since the udder is rich in sphingomyelin (COELHO et al., 2011).

The virulence factors act on the induction and persistence of infections, ensuring the success and survival of the agent. Since the pathogenicity of $S$. aureus depends on these factors, the development of alternatives that promote their inhibition and, consequently, prevent their clinical manifestations (ESCAICH, 2008), becomes a promising strategy.

\section{CONCLUSION}

The identification of biofilm forming antimicrobial multiresistant $S$. aureus reveals the importance of prevention and control of intramammary infections in the herds and of the persistence of the etiological agent in the milking facilities, in order to avoid the propagation of this pathogenic microorganism in the milk production chain.

\section{SUPPLIERS}

${ }^{1}$ Laborclin ${ }^{\circledR}$ Produtos para Laboratório Ltda. Pinhais, Paraná, PR, Brazil.

${ }^{2} \mathrm{Oxoid}^{\circledR}$ Microbiology Products. Hampshire, United Kingdom.

${ }^{3} \mathrm{HiMedia}^{\circledR}$ Laboratories. Mumbai, India.

${ }^{4}$ Difco ${ }^{\mathrm{TM}}$ Microbiologia. Sparks, MD, USA.

${ }^{5}$ Merck Millipore Corporation. Darmstadt, Germany.

${ }^{6} \mathrm{DME}^{\circledR}$ Diagnósticos Microbiológicos Especializados, São Paulo, SP, Brazil.

${ }^{7}$ Cefar ${ }^{\circledR}$ Diagnóstica Ltda, Sensifar e Multifar. São Paulo, SP, Brazil.

${ }^{8}$ Escala de MacFarland ${ }^{\circledR}$ Nefelobac, Probac do Brasil. São Paulo, SP, Brazil.

\section{ACKNOWLEDGEMENTS}

To Capes/Prosup/UPF for supporting this study for supporting this study through scholarships.

\section{REFERENCES}

ACOSTA, A.C. et al. Frequency of Staphylococcus aureus virulence genes in milk of cows and goats with mastitis. Pesq. Vet. Bras. vol.38, n. 11 , pp.2029-2036, 2018.
ARCHER, N.K. et al. Staphylococcus aureus biofilms - Properties, regulation and role in human disease. Virulence, v.2, n.5, p. 445-459, 2011. 
AULETTA, S. et al. Imaging bacteria with radiolabeled quinolones, cephalosporins and siderophores for imaging infection: a systematic review. Clinical and Translational Imaging. 4. 10.1007/s40336-016-0185-8, 2016.

BASSETTI, M. et al. Important new therapies for methicillinresistant Staphylococcus aureus. Expert Opin. Pharmacother. 20, 2317-2334, 2019.

BRASIL. Ministério da Agricultura, Pecuária e Abastecimento. Instrução Normativa no 77 de 26 de novembro de 2018 . Ficam estabelecidos os critérios e procedimentos para a produção, acondicionamento, conservação, transporte, seleção e recepção do leite cru em estabelecimentos registrados no serviço de inspeção oficial. Diário Oficial da União, Brasília DF, 26 de nov. de 2018 . Available at: <http://www.in.gov.br/materia/-/ asset_publisher/KujrwOTZC2Mb/content/id/52750141/ do 1-2018-11-30-instrucao-normativa-n-77-de-26-denovembro-de-2018-52749887>. Accessed on June 23, 2020

BRASIL. Ministério da Agricultura, Pecuária e Abastecimento. Instrução Normativa n 01 , de 13 de janeiro de 2020. Diário Oficial da União, Brasília DF, 13 de jan. de 2020. Available at: <https://www.in.gov.br/en/web/dou/-/instrucao-normativa$\mathrm{n}$-1-de-13-de-janeiro -de-2020-239402385>. Accessed on June 23, 2020.

BrCAST. Método de Disco-difusão EUCAST para Teste de Sensibilidade aos Antimicrobianos. Brazilian Committee on Antimicrobial Susceptibility Testing; v. 6.0, Jan. 2017. Available at: <http://brcast.org.br/documentos/>. Accessed on June 23, 2020.

BONSAGLIA, E.C.R. et al. Molecular epidemiology of methicillinsusceptible Staphylococcus aureus (MSSA) isolated from milk of cows with subclinical mastitis, Microb. Pathog, 124. 130$135,2018$.

BUDI, S. et al. Hydrolytic enzyme activity of Paenibacillus sp. strain B2 and effects of the antagonistic bacterium on cell integrity of two soil-borne pathogenic fungi. Applied Soil Ecology. 15. 191-199, 2001.

CHIH-WEI, L.; YIU-KAY, L.; YU-TSUENG, L. Staphylococcus aureus Hijacks a skin commensal to intensify its virulence: immunization targeting $\beta$ - hemolysin and camp factor. The Journal of Investigative Dermatology, v.131, p.401- 409, 2011.

CLSI. Performance Standards for Antimicrobial Susceptibility Testing. 29th ed. CLSI supplement M100. Wayne, PA: Clinical and Laboratory Standards Institute; 2019.

COELHO, S. et al. Short communication: Profile of virulence factors of Staphylococcus aureus isolated from subclinical bovine mastitis in the state of Rio de Janeiro, Brazil. J. Dairy Sci. 94. 3305-10, 2011.

DA COSTA, G.M. et al. Resistência a antimicrobianos em Staphylococcus aureus isolados de mastite em bovinos leiteiros de Minas Gerais, Brasil. Arq. Inst Biol. 80(3): 297-302, 2013.

DIAS, A.M.G.; Kano, E.; Nakahara, L.K.; Fernandes, S.A.; Kato, M.A.M.F. \& Irino, K. Virulence factors in Escherichia coli isolated from blood and cerebrospinal fluid. Revista de Microbiologia, São Paulo. v. 25 n², p. 77-82, 1994.

DINGES, M. M.; ORWIN, P. M.; SCHLIEVERT, P. M. Exotoxins of Staphylococcus aureus. Clinical Microbiology Reviews. v. 13, n. 1, p.16-34, 2000.
ECONOMOU, V., \& GOUSIA, P. Agriculture and food animals as a source of antimicrobial-resistant bacteria. Infect Drug Resist. 1;8:49-61, Apr. 2015.

ESCAICH S. Antivirulence as a new antibacterial approach for chemotherapy. Current Opinion in Chemical Biology, v. 12, p. 400-408, 2008.

EVANCHO, G. M. et al. Microbiological monitoring of the food processing environment. In: DOWNES, P. F.; ITO, K. Compendium of methods for the microbiological examination of foods. 4. ed. Washington: American Public Health Association (APHA), p.25-35, 2001.

FREITAS, C.H. et al. Identification and antimicrobial susceptibility profile of bacteria causing bovine mastitis from dairy farms in Pelotas, Rio Grande do Sul. Braz. J. Biol. 78, 661-666, 2018.

FREEMAN, D.J., FALKINER, F.R., KEANE, C.T. New method for detecting slime production by coagulase negative Staphylococci. J Clin Pathol., v. 42, p.872-874, 1989.

GUIMARÃES, G. et al. Caracterização fenotípica, produção de biofilme e resistência aos antimicrobianos em isolados de Staphylococcus spp. obtidos de casos de mastite em bovinos e bubalinos. Pesq. Vet. Bras., v.32, n.12, p.1219-1224, 2012.

GRUET P, Maincent P, Berthelot X, Kaltsatos V. Bovine mastitis and intramammary drug delivery: review and perspectives. Adv Drug Deliv Rev. 50(3) 245-259, Sep. 2001.

HEIKKILÄ, A.-M., Liski, E., Pyörälä, S. \& Taponen, S. Pathogenspecific production losses in bovine mastitis. J. Dairy Sci. 101, 9493-9504, 2018.

HIRAMATSU, K. et al. Methicillin-resistant Staphylococcus aureus clinical strain with reduced vancomycin susceptibility. J. Antimicrob. Chemother. 40, 135-136, 1997.

HUYGHEBAERT, G.; DUCATELLE, R.; VAN IMMERSEEL, F. An update on alternatives to antimicrobial growth promoters for broilers. The Veterinary Journal, v. 187, n. 2, p. 182-188, 2011.

KHAN, SHAHPER. N. \& KHAN, ASAD. Breaking the Spell: Combating Multidrug Resistant 'Superbugs'. Frontiers in Microbiology. 6. 1574. 10.3389, 2015.

KOZIEL, J.; POTEMPA, J. Protease-armed bacteria in the skin. Cell Tissue Res. 351, 325-337, 2013.

KRUMPERMAN, P. H. Multiple antibiotic resistance indexing of Escherichia coli to identify high-risk sources of fecal contamination of foods. Applied and Environmental Microbiology, n. 46, v. 1, 165-170, 1983.

LARSEN, H.; AARESTRUP, F.M.; JENSEN, N.E. Geographical variation in the presence of genes encoding super antigenic exotoxins and beta-hemolysin among Staphylococcus aureus isolated from bovine mastitis in Europe and USA. Veterinary microbiology. 85. 61-7, 2002.

LATORRE, A.A. et al. Biofilm in milking equipment on a dairy farm as a potential source of bulk tank milk contamination with Listeria monocytogenes. J. Dairy Sci. 93:2792-2802, 2010.

LE MARÉCHAL, C. et al. Molecular basis of virulence in Staphylococcus aureus mastitis. PLoS ONE. 6: e27354, 2011.

LEVIN-REISMAN, I. et al. Epistasis between antibiotic tolerance, persistence, and resistance mutations. Proceedings of the National Academy of Sciences. 116, 2019. 
LUNDSTROM, TS., SOBEL, J.D. Antibiotics for gram-positive bacterial infections. Infect Dis Clin North Am. 14(2):463474, 2000.

MANYI-LOH, CHRISTY et al. "Antibiotic Use in Agriculture and Its Consequential Resistance in Environmental Sources: Potential Public Health Implications." Molecules. vol. 23,4 795. 30 Mar. 2018.

MARCHAND, S. et al. Biofilm Formation in Milk Production and Processing Environments; Influence on Milk Quality and Safety. Compr Rev Food Sci. F 1 1:133-147, 2012.

MARQUES, V. et al. Análise fenotípica e genotípica da virulência de Staphylococcus spp. e de sua dispersão clonal como contribuição ao estudo da mastite bovina. Pesq. Vet. Bras. 33. 161-170, 2013.

MELCHIOR, M.B.; VAARKAMP, H.; FINK-GREMMELS, J. Biofilms: A role in recurrent mastitis infections? Review. Vet. J., v.171, p.398-407, 2006.

MELO, P. et al. Análise fenotípica e molecular da produção de biofilmes por estirpes de Staphylococcus aureus isoladas de casos de mastite subclínica bovina. Bioscience Journal. 28. 94, 2012.

MENEGOTTO, F.R.; PICOLI, S.U. Staphylococcus aureus oxacilina resistente (MRSA): incidência de cepas adquiridas na comunidade (CA-MRSA) e importância da pesquisa e descolonização em hospital. Rev Bras Anal Clin. 39(2): 147-50, 2007.

MERGHNI, A. et al. High potential of adhesion to biotic and abiotic surfaces by opportunistic Staphylococcus aureus strains isolated from orthodontic appliances. Microbial Pathogenesis. 91. 10.1016/j.micpath.2015.11.009, 2015.

NARMS. "Strategic Plan 2012-2016". NATIONAL ANTIMICROBIAL RESISTANCE MONITORING SYSTEM, 2012. Available at: http://www.fda.gov/downloads/ AnimalVeterinary/SafetyHealth/AntimicrobialResistance/ NationalAntimicrobialResistanceMonitoringSystem/UCM236283. pdf $>$. Accessed on June 23, 2020.

NOEL, C. C. et al. Perfil de Suscetibilidade Antimicrobiana e Produção de "Slime" de Isolados de Staphylococcus spp. Provenientes de casos de Mastite Bovina na Região Sul-Fluminense. Revista de Saúde. 07 (1): 22-26, 2016.

STEPANOVIC S. et al. A modified microtiter-plate test for quantification of staphylococcal biofilm formation. $\mathbf{J}$ Microb Meth 40(2):175-179, 2000.

OLIVEIRA, M. et al. Biofilm-forming ability profiling of Staphylococcus aureus and Staphylococcus epidermidis mastitis isolates. Veterinary Microbiology, v. 118, p.133-140, 2006.

O'RIORDAN K.; Lee J.C. Staphylococcus aureus capsular polysaccharides. Clin. Microbiol. Rev. 17(1):2 18-234, 2004.

PÉREZ-RODRÍGUEZ, F.; MERCANOGLU TABAN, B. A State-of-Art Review on Multi-Drug Resistant Pathogens in Foods of Animal Origin: Risk Factors and Mitigation Strategies. Frontiers in Microbiology. 10. 10.3389/fmicb.2019.02091, 2019.

RABELLO, R. et al. Antimicrobial Resistance in Farm Animals in Brazil: An Update Overview. Animals. 10. 552. 10.3390/ ani $10040552,2020$.
RALL, V.L.M. et al. Diversity of Staphylococcus species and prevalence of enterotoxin genes isolated from milk of healthy cows and cows with subclinical mastitis, J. Dairy Sci, 97. 829837, 2014.

RAZA, A.; MUHAMMAD, G.; SUMAIRA, S.; ATTA, A. Biofilm producing Staphylococcus aureus and bovine mastitis: a review. Mol. Microbiol. Res. 3:1-8, 2013.

REN, Q. et al. Prevalence and characterization of Staphylococcus aureus isolates from subclinical bovine mastitis in southern Xinjiang, China. J. Dairy Sci. 103. 10.3168/jds.2019-17420, 2020.

RESENDE, N.F.M. et al. Avaliação da resistência de bactérias do leite aos antimicrobianos. In: Anais...Encontro de Iniciação Científica da UninCor. Universidade Vale do Rio Verde. Três Corações/MG, 2012.

RODRIGUES, L. et al. Quantification of biofilm production on polystyrene by Listeria, Escherichia coli and Staphylococcus aureus isolated from a poultry slaughterhouse.Braz. J. Microbiol. [online]. vol.41, n.4, pp.1082-1085, 2010.

SATO, T. et al. Association of Veterinary Third-Generation Cephalosporin Use with the Risk of Emergence of ExtendedSpectrum-Cephalosporin Resistance in Escherichia coli from Dairy Cattle in Japan. PloS one. 9. e96101. 10.1371/journal. pone.0096101, 2014.

SCHUKKEN, Y. H. et al. Host-response patterns of intramammary infections in dairy cows. Vet. Immunol. Immunopathol. 144:270-289, 2011.

SILVEIRA-FILHO, V. M. et al. Antibiotic resistance and molecular analysis of Staphylococcus aureus isolated from cow's milk and dairy products in northeast Brazil. J. Food Prot. 77, 583-591, 2014.

STEVENS, M. et al. Antimicrobial consumption on dairy herds and its association with antimicrobial inhibition zone diameters of non-aureus staphylococci and Staphylococcus aureus isolated from subclinical mastitis. J. Dairy Sci. v. 101, p.3311-3322, 2018.

SOULI, M.; GIAMARELLOU, H. Effects of slime produced by clinical isolates of coagulase-negative staphylococci on activities of various antimicrobial agents. Antimicrob. Agents Chemother. 42, 939-941, 1998.

VAZ-MOREIRA, I.; NUNES, O. C.; MANAIA, C. M. Bacterial diversity and antibiotic resistance in water habitats: searching the links with the human microbiome, FEMS Microbiology Reviews, v. 38, n. 4, p. 761-778, 2014.

VIGUIER, Caroline \& Arora, Sushrut \& Gilmartin, Niamh \& Welbeck, Katherine \& O'Kennedy, Richard. Mastitis detection: current trends and future perspectives. Trends in Biotechnology. 27. 486-493, 2009.

WANG, D. et al. Antimicrobial susceptibility, virulence genes, and randomly amplified polymorphic DNA analysis of Staphylococcus aureus recovered from bovine mastitis in Ningxia, China. J. Dairy Sci. 99:9560-9569, 2018.

ZSCHOCK M. et al. Pattern of enterotoxin genes seg, seh, sei and sej positive Staphylococcus aureus isolated from bovine mastitis. Veterinary Microbiology, Amsterdan, v. 108, n. 3, p. $243-249,2005$. 